呈するものが可战りありこれ等を除いては主に細

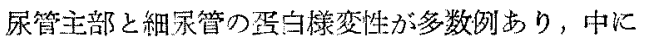

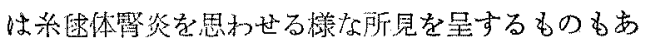
つた. 以上刀如結果上り真菌的混在菌として見摇 ることなく今少し関心を払 5べきだと述べた。

95. 慢性副鼻腔炎之慢性氮管支炎（Sinobronchitis) の臨床的科究 (5 分)

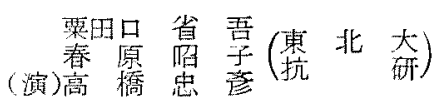

我々は最近6r年间比慢性副舅腔炎と色心な肺突

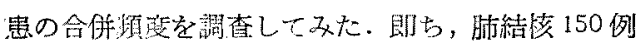

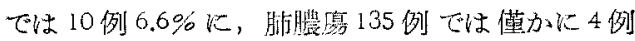
$2.9 \%$ であつたが，氮管支出張症では 220 例中 58 例

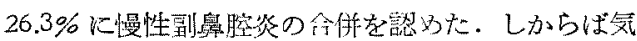
管支战張症乃至恃慢性気管支炎のどの上うなるのに

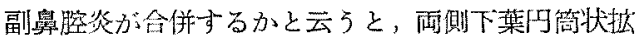
張を呈するものに最も高度に( $83.3 \%$ ) 㤎如られた。 これらの例はむしら慢性文管支竾といらべきであ り，上気道下文道粘膜全般に浮腫を伴 万軽度の慢性

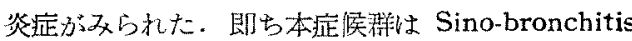
の本態とみなすべき疾患と思秃れる。

本症侯群つ完全治痖は副鼻腔炎の及根治させるこ とは出来ても，肺切稌不能な気管支炎の存在するか ぎり到底不能であり、この方面の洽療仙化学療法に よらなければならない，鼠根治手術を行つて得た本

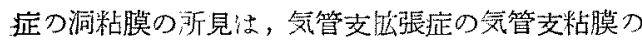

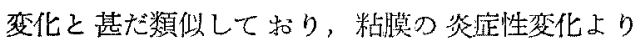
も，粘液性上皮細胞の高度の增稙肪その主な病理的 変化と洘えられた。

96. 鼻出血に関する臨床的班究（第 2 報）

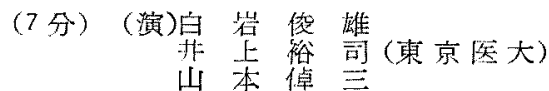

西丸上氏は毛細脈管の構造及び機能は，身体各部によ り琵り，页に一脈管柔でも部位により異ると云つて

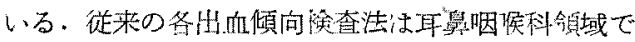
取扱 弓粘膜の特質を考慮していない喥があり，我た

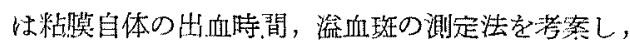

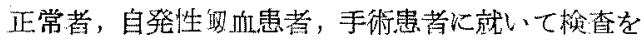
行い，先の成績を検討した。
その結果，絬膜出血頃向挨查汢従来の皮䖉検查上

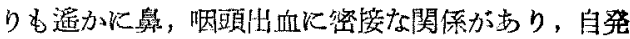
性级血患者に就いてては約 2 倍乃至それ以上粘裳値つ 方が多く暴常を示すことが瑟められた。

又術前飞各種止血剂を使用して手術時の出血状況 を併せて観察したが，血管強化作用のある薬凨に最 も明らかな止血効果が珰邓られた。

\section{7. 慢性副鼻腔炎の実験的研究}

岡田博允(順天堂大)

$2 \mathrm{~kg}$ 前後の健常成熟家鬼を使用し，卵白アルブ ンとて感作した群と感作しない群とに，夫々 A) 卵 白，B）卵白と細菌， C) 細菌老家鬼の副鼻腰内 に注入し慢性副鼻腔炎を起さしめ，約40日間観察 の後，断頭固定し，副鼻腔粘膜及び気管，肺城，心

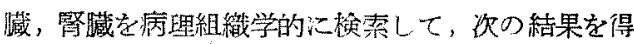
た。

1）往入するものか，卵白，卵当と細菌，細菌何

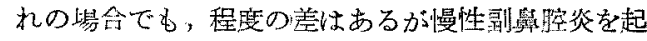
さしめることが出来た。

2）注入した卵白，細菌等による本䁈的な相違は 認め難い

3)アンルギーの'状態にある副鼻腔粘膜は正常秥 膜よりも副畧腔炎を起し易いが，アレルギー性反応 像を見出すことが困難の場合が多い。

4）反覆して長期亘つて，副鼻腽に細菌感染が 起る侍法細菌アレルギーが成立するが，細菌性アレ

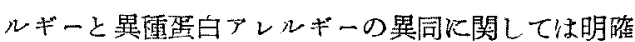
な結論には達しなかつた。

5）副鼻腔感染に基く軽晏の間質性肺炎及び 系速 体腎炎，血管壁のフィブリ１ド变性と，その周囲 に浮腱，細胞浸潤，線維化等が梁められたが，判然 としたアレルギー性反応像の証明汢困難であつた。

\section{○ 98. 慢性副舅腔炎の偏性嫌気性菌に} 関する研究 (2)

小川惣一(東克透信)

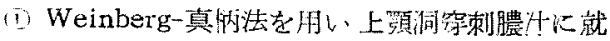

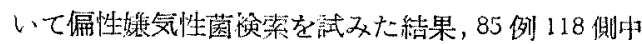
30 例 36 侧 (37 株) 約 $30 \%$ 飞检出儿，想像以上飞嶟 気性菌の存するを知つた．Prévot-真柄の分頑に徉

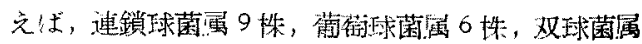

